\title{
Gambaran Kadar Glukosa Darah Sewaktu Pada Penderita Hipertensi di Puskesmas II Mendoyo
}

\author{
Putu Dita Pratiwi ${ }^{1}$, I Gusti Agung Dewi Sarihati ${ }^{2}$, I Gusti Agung Ayu Putu Swastini ${ }^{3}$ \\ ${ }^{1,2}$ Program Studi D III Teknologi Laboratorium Medis Politeknik Kesehatan Denpasar \\ ${ }^{3}$ Program Studi STR Teknologi Laboratorium Medis Politeknik Kesehatan Denpasar
}

\begin{abstract}
Abstrak
Hipertensi merupakan penyakit degeneratif yang masih banyak diderita oleh masyarakat di Provinsi Bali. Hipertensi terjadi karena banyak faktor dimana faktor itu bisa di mulai dari genetik dan pola hidup. Hipertensi dapat menimbulkan resistensi insulin yang merupakan penyebab utama peningkatan glukosa darah, sehingga orang yang menderita hipertensi memiliki risiko menderita diabetes mellitus. Tujuan dari penelitian ini untuk mengetahui gambaran kadar glukosa darah sewaktu pada penderita hipertensi di Puskesmas II Mendoyo. Metode penelitian ini menggunakan jenis penelitian deskriptif kuantitatif yang melibatkan 30 responden yang didapat melalui teknik purposeive sampling. Penelitian dilaksanakan pada Maret - April 2021. Pengumpulan data dilakukan melalui pengisian kuisioner dan pemeriksaan menggunakan alat POCT EasyTouch ${ }^{\circledR}$ GCU. Hasil penelitian menunjukkan sebanyak $(13,3 \%)$ penderita hipertensi memilki kadar glukosa darah sewaktu kategori bukan DM, (80\%) dengan kategori belum pasti DM, dan (6,7\%) dengan kategori DM. Rata - rata kadar glukosa darah sewaktu yaitu 120,7 mg/dLdengan kadar terendah $84 \mathrm{mg} / \mathrm{dL}$ dan kadar tertinggi yairu $273 \mathrm{mg} / \mathrm{dL}$. Dari data tersebut dapat disimpulkan bahwa sebagian besar penderita hipertensi memiliki kadar glukosa darah sewaktu kategori belum pasti DM.
\end{abstract}

Kata kunci : kadar glukosa darah sewaktu; hipertensi; diabetes melitus

\section{Description of Blood Glucose Levels in Hypertension Patients in Mendoyo Public Health Center}

\begin{abstract}
Hypertension is a degenerative disease that still affects many people in Bali Province. Hypertension occurs due to many factors where it can start from genetics and lifestyle. Hypertension can lead to insulin resistance which is the main cause of increased blood glucose, so that people who suffer from hypertension have the risk of suffering from diabetes mellitus. The purpose of this study is to describe the current blood glucose levels in patients with hypertension at Puskesmas II Mendoyo. Method this research uses descriptive quantitative method involving 30 respondents through purposive sampling technique. The research was conducted in March - April 2021. Data collection was carried out by filling out questionnaires and examining blood glukose level with POCT EasyTouch GCU. The results showed that (13.3\%) patients with hypertension had blood glucose levels in the non-DM category, (80\%) with the uncertain DM category, and $(6.7 \%)$ in the DM category. The average blood glucose level is $120.7 \mathrm{mg} / \mathrm{dL}$ with the lowest level is $84 \mathrm{mg} / \mathrm{dL}$ and the highest level up to $273 \mathrm{mg} / \mathrm{dL}$. In conclusion, most patients with hypertension have blood glucose levels during the uncertain DM category.
\end{abstract}

Keywords: blood glucose levels; hypertension; diabetes melitus

Korespondensi : I GustiAgung Dewi Sarihati, Prodi D III TeknologiLaboratoriumMedis, Politeknik Kesehatan Kemenkes Denpasar, Jalan Sanitasi No. 1 Sidakarya Denpasar Bali, mobile 085102777406, e-mail dewisarihati@gmail.com 


\section{Pendahuluan}

Hipertensi merupakan salah satu penyakit kardiovaskular yang paling umum dan paling banyak terjadi pada masyarakat. Data World Health Organization (WHO) tahun 2015 menunjukkan sekitar 1,13 Miliar orang di dunia menyandang hipertensi. Jumlah penyandang hipertensi terus meningkat setiap tahunnya, diperkirakan pada tahun 2025 akan ada 1,5 Miliar orang yang terkena hipertensi, dan diperkirakan setiap tahunnya 10,44 juta orang meninggal akibat hipertensi dan komplikasinya (Kemenkes RI, 2019).

Secara nasional hasil Riskesdas 2018 menunjukkan bahwa prevalensi penduduk dengan hipertensi sebesar 34,11\%. Prevalensi hipertensi pada perempuan $(36,85 \%)$ lebih tinggi dibanding dengan laki-laki (31,34\%). Prevalensi di perkotaan sedikit lebih tinggi $(34,43 \%)$ dibandingkan dengan perdesaan $(33,72 \%)$. Prevalensi semakin meningkat seiring dengan pertambahan umur. Prevalensi tertinggi di Kalimantan Selatan (44.1\%), sedangkan terendah di Papua sebesar $(22,2 \%)$. Estimasi jumlah kasus hipertensi di Indonesia sebesar 63.309.620 orang, sedangkan angka kematian di Indonesia akibat hipertensi sebesar 427.218 kematian. Hipertensi terjadi pada kelompok umur 31-44 tahun (31,6\%), umur 4554 tahun $(45,3 \%)$, umur 55-64 tahun $(55,2 \%)$ (Kemenkes RI, 2019).

Hipertensi didefinisikan sebagai kondisi tekanan darah sistolik $\geq 140 \mathrm{mmHg}$ atau diastolik $\geq 90 \mathrm{mmHg}$ (Kemenkes RI, 2018). Hipertensi terjadi karena banyak faktor dimana faktor itu bisa di mulai dari genetik dan pola hidup. Kondisi ini umumnya jarang menimbulkan gejala dan sering tidak disadari, sehingga dapat menimbulkan morbiditas lain seperti gagal jantung kongestif, hipertrofi ventrikel kiri, stroke, gagal ginjal stadium akhir, atau bahkan kematian. Sehungga hipertensi disebut pembunuh diam-diam atau Silent Killer.

Hipertensi juga merupakan salah satu faktor risiko diabetes mellitus (faktor risiko yang tidak dapat dimodifikasi). Hipertensi dapat menimbulkan resistensi insulin yang merupakan penyebab utama peningkatan glukosa darah, sehingga orang yang menderita hipertensi memiliki risiko menderita diabetes mellitus (Rahayu dkk., 2012).

International Diabetes Federation (IDF) menyebutkan ketika pankreas tidak lagi mampu membuat insulin atau ketika tubuh tidak dapat memanfaatkan secara efektif insulin yang dihasilkannya maka akan menyebabkan kadar glukosa dalam darah tinggi (hiperglikemia). Keadaan hiperglikemia jika terjadi dalam jangka panjang akan berhubungan dengan kerusakan tubuh dan kegagalan berbagai organ dan jaringan (International Diabetes Federation, 2020).

Diagnosis diabetes melitus ditegakkan atas dasar pemeriksaan kadar glukosa darah. Pemeriksaan glukosa darah yang dianjurkan adalah pemeriksaan glukosa secara enzimatik dengan bahan plasma darah vena. Pada keadaan yang tidak memungkinkan dan tidak tersedia fasilitas Tes Toleransi Glukosa Oral (TTGO), maka pemeriksaan penyaring dengan mengunakan pemeriksaan glukosa darah kapiler, diperbolehkan untuk patokan diagnosis diabetes mellitus (PERKENI, 2015).

Skrining kadar gula darah merupakan upaya pencegahan sekunder yang bertujuan untuk sedini mungkin menemukan penderita diabetes melitus atau yang berisiko terkena diabetes melitus, salah satunya dengan pengecekan kadar glukosa darah sewaktu. Pemeriksaan kadar gula darah sewaktu adalah pemeriksaan gula darah yang dilakukan setiap waktu, tanpa ada syarat puasa dan makan (Rachmawati, 2015).

Tujuan penelitian yaitu mengidentifikasi karakteristik responden berdasarkan usia, jenis kelamin, dan pekerjaanserta mengukur kadar glukosa darah sewaktu dan mendeskripsikan kadar glukosa darah sewaktu responden berdasarkan karakteristik.

\section{Metode}

Penelitian ini menggunakan jenis penelitian deskriptif kuantitatif yang melibatkan 30 orang responden. Penentuan responden dilakukan dengan teknik purposive sampling melalui seleksi khusus dengan menetapkan kriteria inklusi dan ekslusi. Penelitian berlangsung pada bulan Maret - April 2021, di Puskesmas II Mendoyo. Data dikumpulkan melalui pengisian kuisoner dan pemeriksaan kadar glukosa darah sewaktu menggunakan alat POCT EasyTouch ${ }^{\circledR} \mathrm{GCU}$.

\section{Hasil}

\section{Karakteristik subjek penelitian}

a. Karakteristik penderita hipertensi berdasarkan usia

Karakteristik responden berdasarkan usia ditemukan sebagian besar responden termasuk dalam kelompok usia 46 - 65 tahun yaitu 24 
orang $(80 \%)$, data selengkapnya dapat dilihat pada tabel 1 .

Tabel 1. Karakteristik Penderita Hipertensi Berdasarkan Usia

\begin{tabular}{cccc}
\hline No & Usia (Tahun) & Jumlah & $\begin{array}{c}\text { Persentase } \\
(\mathbf{\%})\end{array}$ \\
\hline 1 & $\begin{array}{l}26-45 \\
\text { (Dewasa) }\end{array}$ & 6 & 20 \\
\hline 2 & $\begin{array}{l}46-65 \\
\text { (Lansia) }\end{array}$ & 24 & 80 \\
\hline & Total & 30 & 100 \\
\hline
\end{tabular}

b. Karakteristik penderita hipertensi berdasarkan jenis kelamin

Karakteristik responden berdasarkan jenis kelamin ditemukan bahwa mayoritas responden dengan jenis kelamin perempuan sejumlah 18 orang $(60 \%)$, selengkapnya ditampilkan pada tabel 2.

Tabel 2. Karakteristik Penderita Hipertensi Berdasarkan Jenis Kelamin

\begin{tabular}{cccc}
\hline No & JenisKelamin & Jumlah & $\begin{array}{c}\text { Persentase } \\
(\mathbf{\%})\end{array}$ \\
\hline 1 & Laki - laki & 12 & 40 \\
\hline 2 & Perempuan & 18 & 60 \\
\hline & Total & 30 & 100 \\
\hline
\end{tabular}

c. Karakteristik penderita hipertensi berdasarkan pekerjaan

Karakteristik responden berdasarkan jenis pekerjaan ditemukan paling banyak adalah sebagai petani sebanyak7 orang $(23.3 \%)$. Data disajikan pada tabel 3.

Tabel 3. Karakteristik Penderita Hipertensi Berdasarkan Pekerjaan

\begin{tabular}{clcc} 
No & Jenis Pekerjaan & Jumlah & $\begin{array}{c}\text { Persentase } \\
(\%)\end{array}$ \\
\hline 1 & Petani & 7 & 23,3 \\
\hline 2 & Pedagang & 6 & 20 \\
\hline 3 & $\begin{array}{l}\text { PNS/ Pegawai } \\
\text { kontrak }\end{array}$ & 3 & 10 \\
\hline 4 & Guru & 4 & 13,3 \\
\hline 5 & Sopir & 2 & 6,7 \\
\hline 6 & Buruh & 1 & 3,3 \\
\hline 7 & Penjahit & 1 & 3,3 \\
\hline 8 & Perangkat desa & 1 & 3,3 \\
\hline 9 & Wiraswasta & 1 & 3,3 \\
\hline 10 & Tidak bekerja & 4 & 13,3 \\
\hline & Total & 30 & 100 \\
\hline
\end{tabular}

d. Karakteristik penderita hipertensi berdasarkan derajat hipertensi
Karakteristik responden berdasarkan derajat hipertensi ditemukan sebagian besar responden mengalami hipertensi derajat satu dan dua dengan masing masing sebanyak 12 orang (40\%). Hipertensi derajat 1: Tekanan darah sistolik (TDS)140 - $159 \mathrm{mmHg}$ atau tekanan darah diastolik (TDD) $90 \quad-99 \mathrm{mmHg}$, hipertensi derajat 2 : TDS $160-179 \mathrm{mmHg}$ atauTDD : 100 - $109 \mathrm{mmHg}$, Hipertensi derajat 3:TDS $\geq 180 \mathrm{mmHg}$ dan $\mathrm{TDD} \geq 110 \mathrm{mmHg}$. Data selengkapnya ditampilkan pada tabel 4 .

Tabel 4. Karakteristik Penderita Hipertensi Berdasarkan Derajat Hipertensi

\begin{tabular}{cccc}
\hline No & DerajatHipertensi & Jumlah & $\begin{array}{c}\text { Persentase } \\
(\boldsymbol{\%})\end{array}$ \\
\hline 1 & Hipertensi derajat 1 & 12 & 40 \\
\hline 2 & Hipertensi derajat 2 & 12 & 40 \\
\hline 3 & Hipertensi derajat 3 & 6 & 20 \\
\hline & Total & 30 & 100 \\
\hline
\end{tabular}

\section{Hasil pengamatan terhadap subjek penelitian berdasarkan variabel penelitian.}

a. Distribusi kadar glukosa darah sewaktu pada penderita hipertensi di Puskesmas II Mendoyo

Berdasarkan hasil penelitian terhadap kadar glukosa darah sewaktu pada penderita hipertensi di Puskesmas II Mendoyo, didapatkan rata - rata kadar glukosa darah sewaktu pada penderita hipertensi adalah sebesar 120,7 mg/dL, dengan median 111,5 $\mathrm{mg} / \mathrm{dL}$, nilai kadar glukosa darah sewaktu terendah yaitu $84 \mathrm{mg} / \mathrm{dL}$, sedangkan nilai kadar glukosa darah sewaktu tertinggi 273 $\mathrm{mg} / \mathrm{dL}$.Kriteria bukan DMbila GDS $<90 \mathrm{mg} / \mathrm{dL}$, belum pasti DM (GDS 90 - $199 \mathrm{mg} / \mathrm{dL}$ ), DM $(\mathrm{GDS} \geq 200 \mathrm{mg} / \mathrm{dL})$, Dengan menggunakan kriteria ini maka ditemukan sebagian besar responden memiliki kadar glukosa darah sewaktu dengan kategori belum pasti DM yaitu 24 orang $(80 \%)$. Data lengkapnya ditampilkan pada tabel 5 .

Tabel 5. Kadar Glukosa Darah Sewaktu pada Penderita Hipertensi Berdasarkan Kategori PERKENI 2015

\begin{tabular}{clcc} 
No & Kategori & Jumlah & Persentase(\%) \\
\hline 1 & Bukan DM & 4 & 13,3 \\
\hline 2 & $\begin{array}{l}\text { Belum pasti } \\
\text { DM }\end{array}$ & 24 & 80 \\
\hline 3 & DM & 2 & 6,7 \\
\hline & Total & 30 & 100 \\
\hline
\end{tabular}


b. Kadar Glukosa Darah Sewaktu pada

Penderita Hipertensi Berdasarkan Usia

Berdasarkan hasil penelitian, menunjukkan bahwa mayoritas responden memiliki kadar glukosa darah sewaktu kategori bukan DM berasal dari kelompok usia 46 - 65 tahun sejumlah 18 orang (60\%). Data selengkapnya ditampilkan pada tabel 6 .

Tabel 6. Kadar Glukosa Darah Sewaktu pada Penderita Hipertensi Berdasarkan Usia

\begin{tabular}{|c|c|c|c|c|c|c|c|c|c|}
\hline \multirow{3}{*}{ No } & \multirow{3}{*}{ Usia } & \multicolumn{6}{|c|}{ Kadar Glukosa Darah Sewaktu } & \multirow{2}{*}{\multicolumn{2}{|c|}{ Total }} \\
\hline & & \multicolumn{2}{|c|}{ Bukan DM } & \multicolumn{2}{|c|}{ Belum pasti DM } & \multicolumn{2}{|c|}{ DM } & & \\
\hline & & $\mathbf{n}$ & $\%$ & $\mathbf{n}$ & $\%$ & n & $\%$ & $\mathbf{n}$ & $\%$ \\
\hline 1 & $\begin{array}{l}26-45 \\
\text { (Dewasa) }\end{array}$ & - & - & 6 & 20 & - & - & 6 & 20 \\
\hline 2 & $\begin{array}{l}46-65 \\
\text { (Lansia) }\end{array}$ & 4 & 13,3 & 18 & 60 & 2 & 6,7 & 24 & 80 \\
\hline & Jumlah & 4 & 13,3 & 24 & 80 & 2 & 6,7 & 30 & 100 \\
\hline
\end{tabular}

c. Kadar Glukosa Darah Sewaktu pada

Penderita Hipertensi Berdasarkan Jenis

Kelamin

Kadar glukosa darah sewaktu pada responden

berdasarkan jenis kelamin menunjukkan bahwa

mayoritas responden memiliki kadar glukosa darah sewaktu kategori belum pasti DM adalah responden perempuan yaitu 15 orang $(50 \%)$. Data selengkapnya ditampilkan pada tabel 7.

Tabel 7. Kadar Glukosa Darah Sewaktu pada Penderita Hipertensi Berdasarkan Jenis Kelamin

\begin{tabular}{|c|c|c|c|c|c|c|c|c|c|}
\hline \multirow{3}{*}{ No } & \multirow{3}{*}{$\begin{array}{c}\text { Jenis } \\
\text { Kelamin }\end{array}$} & \multicolumn{6}{|c|}{ Kadar Glukosa Darah Sewaktu } & \multirow{2}{*}{\multicolumn{2}{|c|}{ Total }} \\
\hline & & \multicolumn{2}{|c|}{ Bukan DM } & \multicolumn{2}{|c|}{ Belum pasti DM } & \multicolumn{2}{|c|}{ DM } & & \\
\hline & & $\mathbf{n}$ & $\%$ & $\mathbf{n}$ & $\%$ & $\mathbf{n}$ & $\%$ & $\mathbf{n}$ & $\%$ \\
\hline 1 & Laki - laki & 2 & 6,7 & 9 & 30 & 1 & 3,3 & 12 & 40 \\
\hline 2 & Perempuan & 2 & 6,7 & 15 & 50 & 1 & 3,3 & 18 & 60 \\
\hline & Jumlah & 4 & 13,3 & 24 & 80 & 2 & 6,7 & 30 & 100 \\
\hline
\end{tabular}

d. Kadar Glukosa Darah Sewaktu pada

Penderita Hipertensi Berdasarkan

Pekerjaan

Hasil penelitian menunjukkan bahwa mayoritas responden yang memiliki kadar glukosa darah sewaktu kategori belum pasti DM memiliki pekerjaan sebagai petani yaitu 6 orang (20\%). Hasil selangkapnya ditampilkan pada tabel 8 .

Tabel 8. Kadar Glukosa Darah Sewaktu pada Penderita Hipertensi Berdasarkan Pekerjaan

\begin{tabular}{|c|c|c|c|c|c|c|c|c|c|}
\hline \multirow{3}{*}{ No } & \multirow{3}{*}{ Pekerjaan } & \multicolumn{6}{|c|}{ Kadar Glukosa Darah Sewaktu } & \multirow{2}{*}{\multicolumn{2}{|c|}{ Total }} \\
\hline & & \multicolumn{2}{|c|}{ Bukan DM } & \multicolumn{2}{|c|}{$\begin{array}{c}\text { Belum pasti } \\
\text { DM }\end{array}$} & \multicolumn{2}{|c|}{ DM } & & \\
\hline & & $\mathbf{n}$ & $\%$ & $\mathbf{n}$ & $\%$ & $\mathbf{n}$ & $\%$ & $\mathbf{n}$ & $\%$ \\
\hline 1 & Petani & 1 & 3,3 & 6 & 20 & - & - & 7 & 23,3 \\
\hline 2 & Pedagang & 1 & 3,3 & 5 & 16,7 & - & - & 6 & 20 \\
\hline 3 & $\begin{array}{l}\text { PNS/ Pegawai } \\
\text { kontrak }\end{array}$ & - & - & 3 & 10 & - & - & 3 & 10 \\
\hline 4 & Guru & - & - & 3 & 10 & 1 & 3,3 & 4 & 13,3 \\
\hline 5 & Sopir & 2 & 6,7 & - & - & - & - & 2 & 6,7 \\
\hline 6 & Buruh & - & - & 1 & 3,3 & - & - & 1 & 3,3 \\
\hline 7 & Penjahit & - & - & 1 & 3,3 & - & - & 1 & 3,3 \\
\hline 8 & Perangkat desa & - & - & 1 & 3,3 & - & - & 1 & 3,3 \\
\hline 9 & Wiraswasta & - & - & - & - & 1 & 3,3 & 1 & 3,3 \\
\hline 10 & Tidak bekerja & - & - & 4 & 13,3 & - & - & 4 & 13.3 \\
\hline & Jumlah & 4 & 13,3 & 24 & 80 & 2 & 6,7 & 30 & 100 \\
\hline
\end{tabular}




\section{Pembahasan}

Berdasarkan kategori PERKENI 2015, dari 30 penderita hipertensi yang diperiksa, sebanyak 80\% dengan GDS 90-199 mg/dLdan $6,7 \%$ memiliki nilai GDS $\geq 200 \mathrm{mg} / \mathrm{dL}$. Penyakit tekanan darah tinggi (hipertensi) juga merupakan salah satu faktor risiko diabetes mellitus (faktor risiko yang tidak dapat dimodifikasi). Hipertensi salah satunya dapat menimbulkan resistensi insulin yang merupakan penyebab utama peningkatan glukosa darah, sehingga orang yang menderita hipertensi memiliki risiko menderita diabetes mellitus (Rahayu dkk., 2012).

Kondisi hipertensi mungkin muncul mendahului kondisi DM. Namun, dalam beberapa kasus hipertensi dan DM terdeteksi pada saat diagnosis awal. Hipertensi yang kerap bersamaan dengan diabetes atau sebaliknya, akan memengaruhi target organ yang sama dan akan meningkatkan risiko aterosklerosis, retinopati, gagal ginjal dan CVD (Mohan dkk., 2013).

a. Kadar glukosa darah sewaktu penderita hipertensi bedasarkan usia

Berdasarkan karakteristik usia, penderita hipertensi dalam penelitian ini dikelompokkan menjadi kategori dewasa dan lansia. Hasil penelitian menunjukkan bahwa sebagian besar penderita hipertensi berasal dari kelompok lansia (46 - 65 tahun). Penelitian yang dilakukan Nuraeni (2019) menununjukkan, mereka dengan umur tua ( $\geq 45$ tahun) lebih berisiko 8.4 kali (C.I $95 \%$ : OR 2.9-24.2) menderita hipertensi bila dibandingkan dengan mereka yang berumur muda ( $<45$ tahun). Semakin umur bertambah, terjadi perubahan pada arteri dalam tubuh menjadi lebih lebar dan kaku yang mengakibatkan kapasitas dan recoil darah yang diakomodasikan melalui pembuluh darah menjadi berkurang. Pengurangan ini menyebabkan tekanan sistolik menjadi bertambah. Hasil ini sejalan dengan penelitian yang dilakukan oleh Tamamilang dkk (2018) di Puskesmas Paceda mengenai umur menunjukkan bahwa sebagian besar responden yang menderita hipertensi derajat I dan hipertensi derajat II berumur 55-65 tahun. Penelitian ini juga menunjukkan semakin meningkatnya umur berpengaruh terhadap terjadinya hipertensi derajat I dan II.

Pemeriksaan kadar glukosa pada penderita hipertensi menunjukkan bahwa penderita hipertensi usia dewasa memiliki kadar GDS 90 - 199 mg/dL sedangkan. Kelompok lansia memiliki kadar GDS yang bervariasidari< $90-200 \mathrm{mg} / \mathrm{dL}$. Nilai terendah GDS dalam kelompok lansia yaitu sebesar 84 $\mathrm{mg} / \mathrm{dL}$ dan tertinggi $273 \mathrm{mg} / \mathrm{dL}$.

Umur merupakan salah satu faktor mandiri terhadap peningkatan gula darah. Semakin tua usia seseorang maka risiko peningkatan kadar glukosa darah dan gangguan toleransi glukosa akan semakin tinggi. Hal ini disebabkan oleh melemahnya semua fungsi organ tubuh termasuk sel pankreas yang bertugas menghasilkan insulin. Sel pankreas bisa mengalami degradasi yang menyebabkan hormon insulin yang dihasilkan terlalu sedikit sehingga kadar gula darah menjadi tinggi. Peningkatan kadar gula darah juga dapat disebabkan karena terganggunya homeostasis pengaturan gula darah (Putra, 2019). Selain itu pada individu yang berusia lebih tua terdapat penurunan aktivitas mitokondria di sel - sel otot sebesar $35 \%$. Hal ini berhubungan dengan peningkatan kadar lemak di otot sebesar 30\% dan memicu terjadinya resistensi insulin (Wulandari dan Kurnianingsih, 2018).

Responden yang memiliki kadar GDS $\geq$ $200 \mathrm{mg} / \mathrm{dL}$ adalah responden yang berusia lebih dari 50 tahun, hal ini sejalan dengan penelitian yang dilakukan oleh Huda (2016) tentang hubungan antara kadar glukosa darah dengan tekanan darah dapat disimpulkan dari data yang diperoleh yaitu sebanyak 20 orang $(66,67 \%)$ responden yang diperiksa, yang lebih banyak cenderung terkena tekanan darah tinggi atau kadar glukosa di atas normal itu berusia 50 tahun lebih. Sedangkan untuk usia yang kurang dari 50 tahun lebih cenderung sedikit yang terkena tekanan darah tinggi dan kadar glukosa di atas normal. World Health Organization (WHO) menyebutkan bahwa tiap kenaikan satu dekade umur pada seseorang yang telah melampaui usia 30, kadar glukosa darah puasa akan naik sekitar 1-2 mg/dL. Semakin tua usia seseorang maka risiko peningkatan kadar glukosa darah dan gangguan toleransi glukosa akan semakin tinggi.

b. Kadar glukosa darah sewaktu penderita hipertensi bedasarkan jenis kelamin

Hasil penelitian terhadap 30 penderita hipertensi dengan 12 diantara adalah laki - laki dan 18 penderita lainnya adalah perempuan. Laki-laki mempunyai risiko sekitar 2,3 kali lebih banyak mengalami peningkatan tekanan darah sistolik dibandingkan dengan perempuan, karena laki-laki diduga memiliki gaya hidup yang cenderung meningkatkan tekanan darah (Kemenkes RI, 2013). Namun, perempuan akan 
mengalami peningkatan risiko hipertensi setelah menopause yaitu usia diatas 45 tahun. Perempuan yang telah mengalami menopause memiliki kadar estrogen yang rendah. Sedangkan estrogen ini berfungsi meningkatkan kadar High Density Lipoprotein (HDL) yang sangat berperan dalam menjaga kesehatan pembuluh darah (Wahyuni dan Eksanoto, 2013).

Faktor risiko terjadinya penyakit diabetes mellitus salah satunya adalah jenis kelamin. Dimana laki-laki memiliki risiko diabetes yang lebih meningkat cepat dari perempuan. Perbedaan risiko ini dipengaruhi oleh distribusi lemak tubuh. Pada laki-laki, penumpukan lemak terkonsentrasi di sekitar perut sehingga memicu obesitas sentral yang lebih berisiko memicu terjadinya gangguan metabolism (Rudi dan Kwureh, 2017).

Setelah usia 30 tahun, perempuan memiliki risiko yang lebih tinggi dibanding laki-laki.Perempuan lebih berisiko mengidap diabetes karena secara fisik perempuan memiliki peluang peningkatan indeks masa tubuh yang lebih besar. Sindroma siklus bulanan (premenstrual syndrome), pascamenopouse yang membuat distribusi lemak tubuh menjadi mudah terakumulasi akibat proses hormonal tersebut sehingga perempuan berisiko menderita diabetes melitus tipe 2 . Proporsi DM lebih tinggi pada perempuan sebesar $53.2 \%$ dibanding laki-laki sebesar 46.8\% (Wahyuni and Alkaff, 2013).

c. Kadar glukosa darah sewaktu penderita hipertensi bedasarkan pekerjaan

Pada penelitian ini 30 responden yang berpartisipasi memiliki jenis pekerjaan yang bervariasi. Secara garis besar dapat dikelompokkan jumlah responden yang bekerja adalah 26 orang $(86,67 \%)$ sedangkan 4 orang $(13,33 \%)$. lainnya tidak bekerja. Hasil berbeda ditemukan dalam penelitian Hardati dan Ahmad (2017) yang menunjukkan jenis pekerjaan menjadi faktor protektif terhadap hipertensi yaitu PNS/ TNI/ Polri/ BUMN/ BUMD, wiraswasta, petani, nelayan, buruh dan kelompok pekerjaan lainnya. Bekerja dapat mencegah hipertensi karena aktivitas fisik akibat kerja baik untuk peredaran darah, orang yang tidak bekerja berisiko menderita hipertensi 8,95 kali dibandingkan dengan orang yang bekerja. Berdasarkan penelitian tersebut juga diketahui faktor risiko hipertensi pada pekerja meliputi jenis pekerjaan, lingkungan kerja, beban kerja, gaya hidup dan karakteristik pekerja.
Hasil pemeriksaan kadar glukosa pada penderita hipertensi yang bekerja diperoleh rata - rata sebesar 121, $61 \mathrm{mg} / \mathrm{dL}$ sedangkan rata rata kadar glukosa darah sewaktu pada penderita hipertensi yang tidak bekerja yaitu $114,75 \mathrm{mg} / \mathrm{dL}$. Kadar glukosa darah dapat dipengaruhi berbagai faktor, salah satunya adalah aktivitas fisik. Secara teori melakukan aktivitas fisik dapat mengendalikan kadar glukosa darah karena pada saat beraktivitas fisik diperlukan energi yang diubah dari glukosa. Namun, sebuah penelitian oleh Ahmad dkk(2019) menunjukkan bahwa tidak ada hubungan yang bermakna antara status pekerjaan (bekerja atau tidak bekerja) dengan tingkat aktivitas fisik seseorang.

Hasil ini menunjukkan faktor status pekerjaan yang terbagi menjadi bekerja dan tidak bekerja bukanlah satu-satunya hal yang memengaruhi tingkat aktivitas fisik seseorang. Faktor ekonomi dapat berperan sebagai salah satu faktor berpengaruh, contohnya saat terjadi krisis ekonomi cenderung meningkatkan beban ekonomi seseorang dan meningkatkan stres psikologis. Hal ini memicu gaya hidup yang lebih sedenter. Krisis ekonomi juga mempengaruhi kualitas nutrisi seseorang disertai dengan penurunan aktivitas fisik (Ahmad dkk., 2019).

Penelitian oleh Ugahari dkk (2016) didapatkan kesimpulan yaitu dari 52 responden yang merupakan pekerja kantor, 45 pekerja masih memiliki kadar glukosa darah puasa yang normal, 5 pekerja dengan hiperglikemia, dan 2 pekerja dengan hipoglikemia. Pekerja kantor cenderung memiliki gaya hidup kurang aktif. Pekerja kantor tidak memiliki waktu untuk terlibat dalam aktivitas fisik yang cukup. Pekerja kantor sebagian besar memiliki aktivitas fisik kurang dan tergolong aktivitas fisik intensitas ringan. Peningkatan kadar glukosa darah puasa pada pekerja kantor selain dapat disebabkan oleh aktivitas fisik yang kurang dan usia yang bertambah tua dapat juga disebabkan pola makan setiap individu. Pola makan berupa perilaku makan yang tidak sehat, asupan serat yang kurang, konsumsi makanan manis berlebihan, dan tidak membatasi konsumsi pangan menyebabkan kadar glukosa dalam darah terganggu.

Simpulan dari penelitian ini adalah $80 \%$ responden memiliki kadar glukosa darah sewaktu kategori bukan DM,60 \% diantaranya lansia. Sedangkan kategori DM sebanyak 6,7 \% semuanya dari lansia. 
Saran menambahkan variabel lain seperti lama menderita hipertensi, obesitas, kebiasaan merokok/minum alkohol.

\section{Daftar Pustaka}

Ahmad, F.Rahayu, M.A, Putri, A.L.A, Ulfani, A.R., Siti, Z., ErlinaWijayanti, E.(2019). Hubungan Status Pekerjaan dengan Aktivitas Fisik pada Keluarga Binaan di Desa Pangkalan RT 09/03 Kecamatan Teluk Naga dan Desa Kemuning RT 11/03 Kecamatan Kresek, Kabupaten Tangerang, Provinsi Banten. Majalah Kesehatan Pharmamedika, 11(1), pp. 17. doi: 10.33476/mkp.v11i1.859. Available at: https://academicjournal.yarsi.ac.id/index. php/majalah-

Pharamedika/article/view/947.

Hardati, A. T. and Ahmad, R. A. (2017). Aktivitas Fisik dan Kejadian Hipertensi Pada Pekerja: Analisis Data Riskesdas 2013. BKM Journal of Community Medicine and Public Health, 3(2), pp. 467-474. Available at: https://media.neliti.com/media/publicatio ns/237978-none-8b366acc.pdf.

Huda, S. A. (2016). Hubungan Antara Kadar Glukosa Darah Dengan Tekanan Darah Manusia Di Rw 03 Kelurahan Kebayoran Lama Jakarta Selatan. BIOEDUKASI (Jurnal Pendidikan Biologi), 7(2), pp. 144-152. doi: 10.24127/bioedukasi.v7i2.617. Available at:

https://academic.oup.com/eurheartj/articl e/39/33/3021/5079119

IDF. (2020). About Diabetes. Available at : https://www.idf.org/aboutdiabetes/whatis-diabetes.html

Kementerian Kesehatan RI. (2013). Pedoman Teknik Penemuan dan Tatalaksana Hipetensi'. Jakarta : Kementerian Kesehatan Republik Indonesia

Kemenkes RI, (2018). Klasifikasi Hipertensi. Available at:http://p2ptm.kemkes.go.id/infographicp2ptm/hipertensi-penyakit-jantung-danpembuluh-darah/page/28/klasifikasihipertensi
Mohan, V., Seedat, Y. K., \& Pradeepa, R. (2013). The rising burden of diabetes and hypertension in southeast asian and african regions: need for effective strategies for prevention and control in primary health care settings. International journal of hypertension, 2013 , 409083. https://doi.org/10.1155/2013/409083. Available at: https://www.ncbi.nlm.nih.gov/pmc/articl es/PMC3612479/pdf/IJHT2013409083.pdf

PERKENI. (2015).Konsensus Pengelolaan Dan Pencegahan Diabetes Melitus Tipe 2 Di Indonesia 2015

Nuraeni, E. (2019). Hubungan Usia Dan Jenis Kelamin Beresiko Dengan Kejadian Hipertensi Di Klinik X Kota Tangerang. Jurnal JKFT, 4(1), p. 1. doi: 10.31000/jkft.v4i1.1996. Available at: http://jurnal.umt.ac.id/index.php/jkft/artic le/view/1996/1234

Putra, Y. (2019). Tabanan Description of Blood Sugar in Elderly in Nursing Home Wana Sraya Denpasar and in Nursing Home Santi Tabanan. Bali Medika Jurnal, 6(1), pp. 44-49. Available at: https://balimedikajurnal.com/index.php/b $\mathrm{mj} /$ article/download/65/56.

Rachmawati, N. (2015). Gambaran Kontrol Dan Kadar Gula Darah Pada Pasien Diabetes Melitus di Poliklinik Penyakit Dalam RSJ Prof. Dr. Soerojo Magelang. Universitas Diponegoro. doi: $10.32388 / \mathrm{k} 4 \mathrm{~m} 554$

Rahayu, P., Utomo, M. and Setiawan, M. R. (2012). Hubungan Antara Faktor Karakteristik, Hipertensi dan Obesitas dengan Kejadian Diabetes Mellitus di Rumah Sakit Umum Daerah Dr. H. Soewondo Kendal', Jurnal Kedokteran Muhammadiyah, 1(2), pp. 26-32. Available at: https://jurnal.unimus.ac.id/index.php/ked okteran/article/view/1302.

Rudi, A. and Kwureh, H. N. (2017). Faktor Risiko Yang Mempengaruhi Kadar Gula Darah Puasa Pada Pengguna Layanan Laboratorium, Jurnal Ilmiah Ilmu Kesehatan: Wawasan Kesehatan, 3(2), 
pp. 33-39. doi: 10.31227/osf.io/d3kes.

Available at: https://garuda.ristekbrin.go.id/documents/ detail/749903

Tamamilang, C. D., Kandou, G. D. and Nelwan, J. E. (2018). Hubungan Antara Umur Dan Aktivitas Fisik Dengan Derajat Hipertensi Di Kota Bitung Sulawesi Utara, Kesmas, 7(5). Available at:

https://ejournal.unsrat.ac.id/index.php/ke smas/article/view/22132/21833.

Ugahari, L. E., Mewo, Y. M. and Kaligis, S. H. M. (2016). Gambaran kadar glukosa darah puasa pada pekerja kantor, Jurnal e-Biomedik, 4(2). doi: 10.35790/ebm.4.2.2016.14616. Available at: https://media.neliti.com/media/publicatio ns/61730-ID-gambaran-kadar-glukosadarah-puasa-pada.pdf

Wahyuni, S. and Alkaff, R. N. (2013). Diabetes Melitus Pada Perempuan Usia Reproduksi Di Indonesia, Jurnal Kesehatan Reproduksi, 3(1), pp. 46-51. Available at: https://media.neliti.com/media/publicatio ns/107315-ID-diabetes-mellitus-padaperempuan-usia-re.pdf.

Wahyuni and Eksanoto, D. (2013). Hubungan Tingkat Pendidikan dan Jenis Kelamin Dengan Kejadian Hipertensi di Kelurahan Jagalan Di Wilayah Kerja Puskesmas Pucangsawit Surakarta, Jurnal Ilmu Keperawatan Indonesia, 1(1), pp. 112-121. Available at: https://garuda.ristekbrin.go.id/documents/ detail/1688076.

Wulandari, D. and Kurnianingsih, W. (2018). Pengaruh Usia, Stres, dan Diet Tinggi Karbohidrat Terhadap Kadar Glukosa Darah, Jurnal Imiah Rekam Medis dan Informatika Kesehatan, 8(1), pp. 16-25. Available at: https://ojs.udb.ac.id/index.php/infokes/art icle/view/192 